\title{
Booklet Nutrisi Meningkatkan Asupan Makan dan Kadar Albumin pada Pasien Bedah yang Berisiko Malnutrisi
}

\author{
Ida Mardalena1, Umi Istianah¹, Heru Sucipto², Etik Ratnaningsih² \\ ${ }^{1}$ Prodi D IV Keperawatan Poltekkes Kemenkes Yogyakarta \\ ${ }^{2}$ RSUD Panembahan Senopati Bantul Yogyakarta \\ Email: ida.mardalena@gmail.com
}

\begin{abstract}
Abstrak
Malnutrisi pada pasien di Rumah Sakit ada hubungannya dengan peningkatan lama hari rawat inap, peningkatan morbiditas dan mortalitas, peningkatan penggunaan sumber dukungan rumah sakit, meningkatnya risiko komplikasi,gangguan fungsi jantung, paru dan menurunkan fungsi imun pada pasien bedah. Tingginya kasus malnutrisi di rumah sakit ini banyak dilaporkan, pada saat akan pulang dari rumah sakit, rata-rata mengalami penurunan berat badan 5,4\%. Prevalensi malnutrisi di Indonesia masih tergolong tinggi, prevalensi malnutrisi 40\%-60\% terjadi pada pasien bedah digestif. Beberapa penelitian yang menggunakan parameter Subjective Global Assesment (SGA), Indeks Massa Tubuh (IMT), haemoglobin, hematokrit dan albumin menemukan prevalensi malnutrisi masing-masing sebesar 52\%, 15\%, 55\%, 26\%, dan 93\%. Penelitian di Inggris menemukan bahwa promosi pesan singkat untuk memonitor berat badan pada masyarakat telah membantu mengidentifikasi risiko malnutrisi. Penelitian ini bertujuan untuk mengetahui pengaruh penggunaan booklet nutrisi terhadap asupan makan dan kadar albumin pasien bedah. Penelitian ini menggunakan eksperimen dengan Post Test Only with Control Groups Design. Melibatkan 60 responden yang dibagi menjadi 30 responden kelompok perlakuan dan 30 responden kelompok pembanding. Uji statistik menggunakan independen t-test dengan $\mathrm{Cl} 95 \%$. Hasil penelitian terdapat perbedaan yang bermakna rata-rata sisa makan antara pasien bedah yang menggunakan booklet nutrisi dengan yang tidak menggunakan booklet nutrisi pada alpha $5 \%$ dengan nilai $p$ 0,03. Terdapat perbedaan rata-rata nilai serum albumin antara pasien bedah yang menggunakan booklet nutrisi dengan yang tidak menggunakan booklet nutrisi pada alpha 5\% dengan p 0,0001. Kadar albumin serum dan asupan makan meningkat secara signifikan dengan penggunaan booklet nutrisi.
\end{abstract}

Kata Kunci: booklet, nutrisi,pasien bedah

\section{Booklet Nutrition Increasing Intake of Meals and Albumin Levels in Surgical Patients with Malnutrition Risk}

\begin{abstract}
Patients with malnutrition at the hospital have been known was related to an increased in the length of stay in hospitalisation, increased of morbidity and mortality, increased used of hospital resources support, increasing the risk of complications, heart and lung function impairment and lowered immune function in surgical patients. The high malnutrition in hospitals has also been widely reported, at the time of going home from the hospital an average weight loss of $5.4 \%$. In Indonesia, the prevalence of malnutrition is still relatively high, the prevalence of malnutrition $40 \%-60 \%$ in gastrointestinal desease patients. Several studies using parameters Subjective Global Assessment (SGA), Body Mass Index (BMI), haemoglobin, hematocrit and albumin found the prevalence of malnutrition respectively 52\%, 15\%, 55\%, 26\% and 93\%. Research in the UK found that promotional text messages to monitor the weight in the community have helped to identify the risk of malnutrition. The objective of study has to determine the effect of nutrition booklet on food intake and levels of albumin on surgical patients. This study uses an experiment with Post Test Only with Control groups Design. Involved 60 respondents were divided into two groups, the treatment group and the comparison group. Statistical test using independent $t$-test with $95 \% \mathrm{Cl}$. Results of the study there was significant differences average remaining meal among surgical patients who use nutritional booklet that does not use a booklet of nutrition at alpha $5 \%$ with the $p$-value of 0.03 . There are differences in the average value of serum albumin
\end{abstract}


among surgical patients who use nutritional booklet that does not use a booklet of nutrition at alpha 5\%, $p$

0.0001. Serum albumin levels and food intake increased significantly with the use of nutritional booklet.

Keywords: booklets, nutrition, surgical patients

Info Artikel:

Artikel dikirim pada 16 Februari 2017

Artikel diterima pada 31 Maret 2017

DOI : http://dx.doi.org/10.21927/jnki.2017.5(1).76-81

\section{PENDAHULUAN}

Masalah nutrisi yang terjadi pada pasien rawat inap di Rumah Sakit telah dilaporkan pada publikasi tahun 1974 dalam artikel "The Skeleton in the Hospital Closet," oleh Charles Butterworth, Jr, MD yang dipublikasikan dalam Nutrition Today. Artikel ini memicu perubahan dalam praktik, dimana dibutuhkan segera diagnosa dan penatalaksanaan pasien kurang gizi dan mencegah malnutrisi yang tidak diketahui (1).

Malnutrisi merupakan kondisi dimana tubuh mengalami kekurangan gizi baik zat gizi makro maupun zat gizi mikro. Malnutrisi dapat terjadi pada masyarakat maupun pada pasien yang dirawat di rumah sakit. Masalah malnutrisi pada pasien yang dirawat masih merupakan isu yang serius, terjadi pada sebagian besar pasien pada semua rentang usia mulai neonatus sampai pasien geriatri, keadaan ini membutuhkan perhatian dari petugas kesehatan dalam hal diagnosis, penatalaksanaan dan pencegahan malnutrisi pada pasien rawat inap (2).

Memperkirakan prevalensi malnutrisi pada pasien yang dirawat dirumah sakit memang cukup sulit. Lebih dari 34 tahun ini para peneliti telah menggunakan alat ukur yang berbeda-beda untuk mendefenisikan malnutrisi (3-11). Belum ada standar emas yang baku atau satu cara penilaian status gizi yang dapat diterima oleh semua kalangan dalam menentukan malnutrisi pada semua kondisi. Penelitian telah dikembangkan pada berbagai masyarakat yang berbeda dalam hal status sosial ekonomi, tingkat pendidikan, kelompok usia serta berat ringan penyakit. Berdasarkan dari banyak penelitian yang telah dilaporkan, diperkirakan $13 \%$ sampai dengan $69 \%$ dari pasien yang dirawat di rumah sakit di Eropa mengalami malnutrisi $(10,6,7,4,3)$. Faktor yang menyebabkan kondisi tersebut terutama asupan makan dan kondisi penyakit terutama pembedahan. Malnutrisi dihubungkan dengan peningkatan lama hari rawat inap, peningkatan morbiditas dan mortalitas, gangguan fungsi jantung dan paru, menurunkan fungsi imun dan gangguan pertumbuhan pada bayi dan pasien bedah. Prevalensi malnutrisi terjadi pada $44 \%$ atau lebih pada pasien rawat inap di Inggris telah dilaporkan oleh Bistrian. Kriteria malnutrisi tersebut menggunakan pengukuran antropometri, kadar albumin serum dan kadar hematokrit. Kadar albumin serum merupakan indikator yang banyak dipakai untuk menentukan kriteria pasien malnutrisi pada beberapa penelitian $(6,7,4,3,5,12)$. Saat ini penilaian malnutrisi pada pasien rawat inap juga menggunakan Indeks Massa Tubuh (IMT), subjective global assessment (SGA), atau komponen lain seperti penurunan berat badan dan asupan makan (4,6-9,11,13-15).

Penelitian yang dimulai tahun 1998 sampai tahun 2003 di British Inggris pada 2.283 pasien, dimana malnutrisi diidentifikasi melalui kehilangan berat badan, asupan kurang, penyembuhan dan infeksi luka, terjadi penurunan malnutrisi dari $23,5 \%$ pada tahun 1998 menjadi $19,1 \%$ pada tahun 2003 (14).

Penelitian pengaruh komunikasi informasi dan edukasi (KIE) gizi dengan menggunakan leaflet, poster dan resep bahan makanan lokal, pada pola makan lokal dan non lokal meningkatkan kecukupan asupan energi dan kecukupan asupan karbohidrat (16). Penerapan metode 'red trays' telah mampu mengidentifikasi pasien malnutrisi dan meningkatkan asupan makan pasien $(1,17)$.

\section{BAHAN DAN METODE}

Penelitian ini merupakan penelitian eksperimen menggunakan postest only with control-group design. Responden yang dilibatkan adalah pasien bedah yang berisiko mengalami malnutrisi yang dirawat di RSUD Panembahan Senopati Bantul selama periode bulan Mei sampai dengan September 2016. Sampel dipilih dengan teknik simple random sampling sebanyak 60 responden yang dibagi menjadi dua kelompok yaitu 30 responden kelompok perlakuan dan 30 responden 
kelompok kontrol. Booklet pada penelitian ini berupa buku yang dicetak dengan kertas hard glossy ukuan setengah folio, berisi 15 halaman pesan nutrisi untuk pasien bedah terdiri dari diet sebelum dan sesudah operasi, tujuan konsumsi makanan bagi penyembuhan, jenis makanan yang dianjurkan untuk dimakan, pilihan makanan bagi pasien bedah serta petunjuk diet setelah operasi yang disertai gambar yang menarik asupan makan responden dinilai menggunakan format taksiran visual sisa makan yang dikembangkan Comstock (18). Penilaian sisa makan dilakukan setiap tiga kali sehari pada saat makan makanan utama yaitu makan pagi makan siang dan makan malam dilakukan baik pada kelompok yang diberikan booklet maupun pada kelompok kontrol. Sebelum analisis statistik dilakukan terlebih dahulu dilakukan uji normalitas data dengan menggunakan uji Kolmogorov-Smirnov. Uji normalitas didapatkan data berdistribusi normal, analisis dilanjutkan dengan independent $t$ test dengan $95 \% \mathrm{Cl}$.

\section{HASIL DAN BAHASAN}

\section{Karakteristik Responden}

Karakteristik responden yang terlibat dalam penelitian ini meliputi 60 pasien bedah yang berisiko malnutrisi yang dirawat di ruang rawat Bougenvil 30 orang dan ruang rawat Melati 30 orang berusia antara 19 sampai dengan 84 tahun disajikan dalam Tabel 1.

Tabel 1. Distribusi Karakteristik Jenis Kelamin Responden di RSUD Bantul

\begin{tabular}{ccccc}
\hline $\begin{array}{c}\text { Variabel } \\
\text { Jenis }\end{array}$ & \multicolumn{2}{c}{$\begin{array}{c}\text { Kelompok } \\
\text { Perlakuan } \\
\mathbf{n = 3 0}\end{array}$} & \multicolumn{3}{c}{$\begin{array}{c}\text { Kelompok } \\
\text { Pembanding } \\
\mathbf{n = 3 0}\end{array}$} \\
\cline { 2 - 5 } Kelamin & $\mathbf{n}$ & $\mathbf{\%}$ & $\mathbf{n}$ & $\%$ \\
\hline Laki-laki & 9,0 & 30,0 & 11,0 & 36,6 \\
Perempuan & 21,0 & 70,0 & 19,0 & 63,4 \\
\hline
\end{tabular}

Sumber: Data Primer Tahun 2016
Berdasarkan pada Tabel 1 karakteristik menurut jenis kelamin pada kelompok perlakuan $30 \%$ berjenis kelamin laki-laki dan $70 \%$ berjenis kelamin perempuan, sedangkan pada kelompok pembanding $36,6 \%$ berjenis kelamin laki-laki dan $63,4 \%$ berjenis kelamin perempuan. Karakteristik responden pada kelompok perlakuan dideskripsikan menurut umur didapatkan umur paling muda berusia 19 tahun dan paling tua 84 tahun, rata-rata berumur 50,53 tahun dengan standar deviasi 14,97 sedangkan pada kelompok pembanding untuk umur yaitu paling muda 22 tahun dan paling tua 84 tahun, rata-rata berumur 53,93 tahun dengan standar deviasi 16,14.

\section{Albumin Serum}

Status gizi responden dinilai dari kadar albumin serum. Hasil penelitian kadar albumin serum sesuai Tabel 2 memperlihatkan bahwa pada kelompok perlakuan, dari 30 responden kadar albumin serum terendah adalah $2,71 \mathrm{~g} / \mathrm{dL}$, kadar albumin serum tertinggi $3,50 \mathrm{~g} / \mathrm{dL}$. Rata-rata kadar albumin serum kelompok perlakuan $3,50 \mathrm{~g} / \mathrm{dL}$ dengan standar deviasi $0,34 \mathrm{~g} / \mathrm{dL}$. Kadar albumin serum pada kelompok pembanding paling rendah 2,61 g/dL, kadar albumin serum paling tinggi $4,05 \mathrm{~g} / \mathrm{dL}$. Nilai rata-rata kadar albumin serum kelompok pembanding adalah 3,15 $\mathrm{g} / \mathrm{dL}$ dengan standar deviasi $0,33 \mathrm{~g} / \mathrm{dL}$.

\section{Asupan Makan}

Status gizi dipengaruhi oleh asupan makan pasien, maka pada penelitian ini asupan makan pasien dinilai dengan menghitung sisa makan di tray pasien yang dilihat dari persentase makanan yang dimakan dan didapatkan hasil sesuai Tabel 3.

Hasil penelitian seperti yang terlihat pada Tabel 3 menunjukkan bahwa pada kelompok perlakuan, rata-rata sisa makan responden $22,82 \%$ atau jumlah

Tabel 2. Nilai Rata-Rata Kadar Albumin Serum Pasien Bedah di RSUD Bantul Yogyakarta

\begin{tabular}{ccccccccc}
\hline \multirow{2}{*}{ Variabel } & \multicolumn{4}{c}{ Kelompok Perlakuan } & \multicolumn{3}{c}{ Kelompok Pembanding } \\
\cline { 2 - 9 } & Min & Max & Mean & Std Dev. & Min & Max & Mean & Std Dev. \\
\hline Albumin serum & $2,71 \mathrm{~g} / \mathrm{dL}$ & $4,22 \mathrm{~g} / \mathrm{dL}$ & $3,50 \mathrm{~g} / \mathrm{dL}$ & $0,34 \mathrm{~g} / \mathrm{dL}$ & $2,61 \mathrm{~g} / \mathrm{dL}$ & $4,05 \mathrm{~g} / \mathrm{dL}$ & $3,15 \mathrm{~g} / \mathrm{dL}$ & $0,33 \mathrm{~g} / \mathrm{dL}$ \\
\hline
\end{tabular}

Sumber: Data Primer Tahun 2016

Tabel 3. Rata-Rata Sisa Makan Pasien Bedah di RSUD Bantul Yogyakarta

\begin{tabular}{ccccccccc}
\hline \multirow{2}{*}{ Variabel } & \multicolumn{3}{c}{ Kelompok Perlakuan } & \multicolumn{3}{c}{ Kelompok Pembanding } \\
\cline { 2 - 9 } & Min & Max & Mean & Std Dev. & Min & Max & Mean & Std Dev. \\
\hline Sisa Makan & $3,75 \%$ & $51,00 \%$ & $22,82 \%$ & $14,13 \%$ & $11,58 \%$ & $78,33 \%$ & 36,08 & 18,25 \\
\hline
\end{tabular}

Sumber: Data Primer Tahun 2016 
konsumsi makanan rata-rata pasien adalah $77,18 \%$. Sedangkan pada kelompok pembanding rata-rata sisa makan pasien $36,08 \%$ artinya jumlah konsumsi makan rata-rata adalah 63,92\%. Hasil uji t untuk kadar serum albumin ditampilkan pada Tabel 4.

Tabel 4. Distribusi Rata-Rata Kadar Albumin Serum Pasien Bedah Menurut Penggunaan Booklet Nutrisi di RSUD Bantul Yogyakarta

\begin{tabular}{lccccc}
\hline $\begin{array}{c}\text { Penggunaan } \\
\text { Booklet }\end{array}$ & Mean & SD & SE & p-value & N \\
\hline Ya Booklet & 3,509 & 0,343 & 0,626 & 0,0001 & 30 \\
\hline Non Booklet & 3,159 & 0,339 & 0,619 & & \\
\hline
\end{tabular}

Sumber: Data Primer Tahun 2016

Hasil uji statistik didapatkan nilai $p=0,0001$, berarti pada alpha $5 \%$ terdapat perbedaan yang signifikan rata-rata kadar albumin antara pasien bedah yang diberikan booklet nutrisi dengan yang tidak diberikan booklet nutrisi. Hasil uji independen $t$ test untuk sisa makan dengan menggunakan Comstock dapat dilihat pada Tabel 5.

Tabel 5. Distribusi Rata-Rata Sisa Makan Pasien Bedah Menurut Penggunaan Booklet Nutrisi di RSUD Bantul Yogyakarta

\begin{tabular}{cccccc}
\hline $\begin{array}{c}\text { Penggunaan } \\
\text { Booklet }\end{array}$ & Mean & SD & SE & p-value & N \\
\cline { 1 - 4 } Ya Booklet & 22,826 & 14,136 & 2,580 & 0,03 & 30 \\
\cline { 1 - 3 } Non Booklet & 36,083 & 18,258 & 3,333 & & \\
\hline
\end{tabular}

Sumber: Data Primer Tahun 2016

Berdasarkan pada Tabel 5 rata-rata sisa makan pasien bedah yang menggunakan booklet nutrisi adalah $22,826 \%$ dengan standar deviasi $14,136 \%$, sedangkan pada pasien yang tidak menggunakan booklet nutrisi, rata-rata sisa makannya adalah $36,083 \%$ dengan standar deviasi $18,258 \%$. Hasil uji statistik didapatkan nilai $p=0,03$, berarti pada alpha $5 \%$ terdapat perbedaan yang signifikan rata-rata sisa makan pasien bedah yang diberikan booklet nutrisi dibandingkan dengan yang tidak menggunakan booklet nutrisi.

Hasil analisis statistik menggunakan independen t-test menunjukkan rata-rata kadar albumin serum dengan menggunakan booklet nutrisi adalah $3,509 \mathrm{~g} /$ $\mathrm{dL}$ dengan standar deviasi $0,343 \mathrm{~g} / \mathrm{dL}$. Hasil uji statistik didapatkan nilai $p=0,0001$, maka dapat disimpulkan ada perbedaan yang signifikan kadar albumin serum pada pasien yang menggunakan booklet nutrisi dengan yang tidak menggunakan booklet nutrisi.
Penelitian ini telah menerapkan metode booklet nutrisi, terbukti bahwa penggunaan booklet nutrisi ini dapat meningkatkan kadar albumin pasien secara signifikan melalui peningkatan asupan makan. Pasien yang kurang diberikan perhatian pada masalah makan akan menurun kadar albuminnya seperti penelitian Saryono, dkk yang menemukan rata-rata kadar albumin pasien menurun dari 2,88 $\mathrm{g} / \mathrm{dL}$ menjadi $2,52 \mathrm{~g} / \mathrm{dL}$ secara bermakna $(p=0,003)$ setelah satu sampai dua minggu dirawat di rumah sakit (19). Banyak faktor yang memengaruhi kadar albumin, faktor yang dapat meningkatkan kadar albumin meliputi: dehidrasi, marasmus, transfusi dan albumin eksogen, sedangkan faktor-faktor yang dapat menurunkan kadar albumin meliputi: overhidrasi / ascites/eklampsia; kegagalan hepar; inflamasi/infeksi/ metabolik stres; nefroptik sindrom,luka bakar, keadaan kehilangan protein, status post trauma/operasi; kwashiorkor; penyakit kolagen; kanker; penggunaan kortikosteroid, tirah baring; defisiensi seng; dan kehamilan (20). Albumin dipengaruhi juga oleh faktor lain selain nutrisi, dan berkorelasi kuat dengan angka kematian dan kesakitan. Albumin juga merupakan penanda status gizi yang efektif dan sensitif terhadap perubahan asupan makan. Meningkatkan asupan gizi secara konsisten akan meningkatkan kadar albumin sebaliknya menurunnya asupan makan menyebabkan menurunkan kadar albumin (20). Malnutrisi telah dilaporkan menyebabkan lama hari rawat menjadi memanjang, pasien yang dirawat dengan kondisi malnutrisi memiliki rata-rata hari rawat lebih lama 4 hari dibandingkan dengan pasien yang tidak malnutrisi (21).

\section{Pengaruh Booklet Nutrisi Terhadap Asupan Makan}

Hasil analisis statistik memperlihatkan ratarata sisa makan pada pasien yang menggunakan booklet nutrisi adalah 22,826\% dengan SD 14,136\% sedangkan pasien yang tidak menggunakan booklet rata-rata sisa makannya adalah $36,083 \%$ dengan SD $18,258 \%$. Hasil uji statistik didapatkan nilai $p=0,03$ maka dapat disimpulkan ada perbedaan yang signifikan antara sisa makan pada pasien yang menggunakan booklet nutrisi, dibandingkan dengan yang tidak menggunakan booklet nutrisi. Banyak faktor yang memengaruhi terjadinya akut malnutrisi, menurut Barker, Gout, dan Crowe faktor pada diri individu meliputi: umur; depresi; penyakit (seperti kanker, diabetes, jantung, gastrointestinal), ketidakmampuan 
membeli atau memasak makanan, ketidakmampuan menelan atau mengunyah, keterbatasan mobilitas fisik, kerusakan sensori (misalnya penciuman, rasa/ taste), tindakan perawatan (ventilasi, pembedahan, pemasangan drain); terapi obat. Faktor dari organisasi termasuk diantaranya adalah kurang adekuatnya intake nutrisi, kurangnya staff yang membantu makan, dan nutrisi penting yang tidak diberikan kepada pasien (22).

Kondisi medis dan kurangnya makanan merupakan kontributor utama terjadinya malnutrisi di negara berkembang. Kurang gizi pada lanjut usia (lansia) terjadi pada 5-12\% dimasyarakat, $30-61 \%$ lansia yang dirawat di rumah sakit, dan $40-80 \%$ lansia yang dirawat dalam jangka waktu lama. Umur berhubungan dengan asupan energi yang kurang. Umumnya satu dari lima lansia di masyarakat mengkonsumsi kurang dari $1.000 \mathrm{Kcal} /$ hari, bandingkan dengan konsumsi usia dewasa sebesar 2.100-2.300 Kcal/hari dan asupan energi dewasa muda yang mencapai $2.700 \mathrm{Kcal} /$ hari (23).

Banyak metode yang telah disarankan khususnya yang berkaitan dengan peran tenaga kesehatan yang profesional termasuk diantaranya mengembangkan kebijakan lokal untuk penatalaksanaan pasien malnutrisi yang melibatkan berbagai disiplin ilmu yang kesemuanya dapat mendukung perbaikan nutrisi pasien (24). Metode Red tray merupakan salah satu alternatif untuk mengatasi malnutrisi pada pasien rawat inap, dengan dipasangnya label pada tempat makan pasien dengan warna yang mencolok, akan menarik perhatian baik pasien maupun tenaga kesehatan yang terlibat dalam perawatan pasien tersebut (1). Penggunaan booklet nutrisi pada pasien bedah ini merupakan salah satu alternatif yang dapat digunakan oleh rumah sakit untuk mempertahankan atau meningkatkan status gizi pasien bedah yang dirawat di tengah keterbatasan sumber daya manusia untuk melakukan penyuluhan secara individu pada pasien tersebut.

\section{SIMPULAN DAN SARAN}

Berdasarkan hasil dan bahasan terdapat perbedaan yang signifikan rata-rata kadar albumin pada pasien bedah yang menggunakan booklet nutrisi dibandingkan dengan tanpa booklet nutrisi pada alpha $5 \%$ dengan $p=0,0001$. Terdapat perbedaan yang signifikan kata-rata asupan makan pada pasien bedah yang menggunakan booklet nutrisi dibandingkan dengan tanpa booklet nutrisi pada alpha $5 \%$ dengan $p=0,03$.
Bagipetugas kesehatanagardapatmenggunakan booklet nutrisi sebagai salah satu metode alternatif yang dapat digunakan untuk meningkatkan kadar albumin dan asupan makan pasien bedah. Bagi rumah sakit agar dapat mempertimbangkan booklet nutrisi sebagai salah alternatif media penyuluhan pada pasien bedah.

\section{RUJUKAN}

1. Mardalena I, Istianah U. Red Tray Strategi Meningkat Status Gizi Pasien Malnutrisi di RSUP Dr. Sardjito Yogyakarta. J Teknol Kesehat. 2015;11(1):6-11.

2. Theresa A. Fessler. Malnutrition: A Serious Concern for Hospitalized Patients. Today's Dietit [Internet]. 2008 [cited 2017 Mar 29];10(7):44. Available from: http://www.todaysdietitian.com/ newarchives/063008p44.shtml.

3. ASPEN. The ASPEN Nutrition Support Core Curriculum: A Case-Based Approach — The Adult Patient [Internet]. American Society of Parenteral and Enteral Nutrition; 2007 [cited 2017 Mar 29]. Available from: https://pdfs.semanticscholar.org/ b842/22b26e5f2aad80c61dd75f294e0acadd2b1 7.pdf.

4. Correia MITD, Campos ACL, ELAN Cooperative Study. Prevalence of hospital malnutrition in Latin America: the multicenter ELAN study. Nutrition [Internet]. 2003 Oct; 19(10):823-5. Available from: http://www.ncbi.nlm.nih.gov/pubmed/14559314.

5. Fuhrman MP, Charney P, Mueller CM. Hepatic proteins and nutrition assessment. J Am Diet Assoc [Internet]. 2004 Aug;104(8):1258-64. Available from: http://www.ncbi.nIm.nih.gov/ pubmed/15281044.

6. Kelly IE, Tessier S, Cahill A, Morris SE, Crumley A, McLaughlin D, et al. Still hungry in hospital: identifying malnutrition in acute hospital admissions. QJM [Internet]. 2000 Feb;93(2):93-8. Available from: http://www.ncbi.nIm.nih.gov/ pubmed/10700479.

7. Kondrup J, Johansen N, Plum LM, Bak L, Larsen IH, Martinsen A, et al. Incidence of nutritional risk and causes of inadequate nutritional care in hospitals. Clin Nutr [Internet]. 2002 Dec;21(6):461-8. Available from: http://www.ncbi.nlm.nih.gov/ pubmed/12468365.

8. Mueller C, Compher C, Ellen DM, American Society for Parenteral and Enteral Nutrition (A.S.P.E.N.) Board of Directors. A.S.P.E.N. clinical 
guidelines: Nutrition screening, assessment, and intervention in adults. JPEN J Parenter Enteral Nutr [Internet]. 2011 Jan;35(1):16-24. Available from: http://www.ncbi.nlm.nih.gov/ pubmed/21224430.

9. Russell MK. Functional assessment of nutrition status. Nutr Clin Pract [Internet]. 2015 Apr;30(2):211-8. Available from: http://www.ncbi. nIm.nih.gov/pubmed/25681483.

10. Weinsier RL, Hunker EM, Krumdieck CL, Butterworth CE. Hospital malnutrition. A prospective evaluation of general medical patients during the course of hospitalization. Am J Clin Nutr [Internet]. 1979 Feb;32(2):418-26. Available from: http://www.ncbi.nlm.nih.gov/ pubmed/420132.

11. Singh $H$, Watt $K$, Veitch $R$, Cantor M, Duerksen DR. Malnutrition is prevalent in hospitalized medical patients: are housestaff identifying the malnourished patient? Nutrition [Internet]. 2006 Apr;22(4):350-4. Available from: http://www.ncbi. nlm.nih.gov/pubmed/16457988.

12. Pagana K, Pagana T. Mosby's Manual of Diagnostic and Laboratory Tests. 3rd ed. Mosby Inc; 2006.

13. McWhirter JP, Pennington CR. Incidence and recognition of malnutrition in hospital. BMJ [Internet]. 1994 Apr 9;308(6934):945-8. Available from: http://www.ncbi.nlm.nih.gov/ pubmed/8173401.

14. O'Flynn J, Peake H, Hickson M, Foster D, Frost $G$. The prevalence of malnutrition in hospitals can be reduced: results from three consecutive cross-sectional studies. Clin Nutr [Internet]. 2005 Dec;24(6):1078-88. Available from: http://www. ncbi.nlm.nih.gov/pubmed/16219393.

15. Pirlich M, Schütz T, Kemps M, Luhman N, Minko N, Lübke $\mathrm{HJ}$, et al. Social risk factors for hospital malnutrition. Nutrition [Internet]. 2005 Mar;21(3):295-300. Available from: http://www. ncbi.nlm.nih.gov/pubmed/15797669.
16. Manusiwa R, Sudarso T. Komunikasi, Informasi \& Edikasi Gizi Kearifan Lokal, Pola Makan, Asupan dan Status Gizi. Universitas Gadjah Mada; 2011.

17. Bradley L, Rees C. Reducing nutritional risk in hospital: the red tray. Nurs Stand [Internet]. 2003;17(26):33-7. Available from: http://www.ncbi. nlm.nih.gov/pubmed/12677818.

18. Comstock EM, St Pierre RG, Mackiernan YD. Measuring individual plate waste in school lunches. Visual estimation and children's ratings vs. actual weighing of plate waste. J Am DietAssoc [Internet]. 1981 Sep;79(3):290-6. Available from: http://www. ncbi.nlm.nih.gov/pubmed/7264115.

19. Saryono, Prastowo A, Anggraeni MD. Perbedaan Kadar Albumin Plasma pada Pasien Sebelum dan Setelah Menjalani Rawat Inap di RSUP Prof. Dr, Margono Soekarjo Purwokerto. J Keperawatan Soedirman. 2006;1(1).

20. Banh L. Serum proteins as markers of nutrition: What are we treating? Pract Gastroenterol. 2006;30(10):46-64.

21. Middleton $\mathrm{MH}$, Nazarenko G, Nivison-Smith I, Smerdely P. Prevalence of malnutrition and 12-month incidence of mortality in two Sydney teaching hospitals. Intern Med J [Internet]. 2001 Nov;31(8):455-61. Available from: http://www.ncbi. nlm.nih.gov/pubmed/11720058.

22. Barker L, Gout B, Crowe T. Hospital Malnutrition: Prevalence, Identification and Impact on Patients and the Healthcare System. Int J Environ Res Public Health [Internet]. 2011 Feb 16;8(12):514-27. Available from: http://www.mdpi.com/16604601/8/2/514/.

23. Seiler WO. [Nutritional status of ill elderly patients]. Z Gerontol Geriatr [Internet]. 1999 Jul;32 Suppl 1:I7-11. Available from: http://www.ncbi.nlm.nih. gov/pubmed/10441797.

24. YouGov The Patients Association. Malnutrition In The Community and Hospital Setting. Abbot Nutrition; 2011. 